Acta Manilana 64 (2016), pp. 59-66

Printed in the Philippines

ISSN: 0065-1370

\title{
Mathematical modeling of thin-layer drying kinetics of carabao mango in a hot-air dryer
}

\author{
Fidel Ivan T. Labutong, Janet Stephanie F. Pastores, Angelyn C. Yeung \\ $\mathcal{E}$ Lola Domnina B. Pestaño* \\ Department of Chemical Engineering, Faculty of Engineering \\ University of Santo Tomas, 1015 Manila, Philippines
}

\begin{abstract}
Carabao mango, also known as the Philippine mango, is one of the most important varieties of mango cultivated in the Philippines. Like any other fruit, carabao mango is susceptible to various diseases making it highly perishable and has a very short span of shelf life. One way of extending the shelf life of carabao mango is through drying. Drying mango meat slices until moisture content (MC) of the mango pulp at $12 \%$ inhibits the growth of microorganisms and the action of enzymes that causes spoilage. This research aims to develop a drying method to determine the suitable thin-layer mathematical model that describes the drying kinetics of thinly sliced carabao mangoes and subsequently to predict the optimum drying temperature and drying time to attain 12\% MC in the mango pulp. Three mathematical models, namely, Laplace Transform Model, Page Model, and Non-linear Decomposition Model were examined to describe the drying behavior of thin mango slices at 60,70 , and $80^{\circ} \mathrm{C}$ using a hot-air batch dryer. Laplace Transform model gave the best fit with the least total error. The optimum temperature was observed to be at $60^{\circ} \mathrm{C}$ being more efficient to produce quality dried carabao mangoes at the shortest drying time of $209.51 \mathrm{~min}$.
\end{abstract}

Keywords: carabao mango, drying kinetics, hot-air batch dryer, mathematical modeling

\section{INTRODUCTION}

Mango (Mangifera indica) is one of the top important fruit crops grown in the Philippines. It ranks third next to banana and pineapple based on volume export and value. Fresh and processed mangoes have already established inside and out of the Philippines where Hong Kong and Japan absorb 89\% of the country's export [1]. Carabao mango, also known as the Philippine mango, is one of the most important

*To whom correspondence should be addressed lbpestano@ust.edu.ph varieties of mango cultivated in the Philippines. The variety is reputed internationally due to its sweetness and exotic taste [2]. Carabao mango like any other fruit is susceptible to various diseases making it highly perishable and has a very short span of shelf life. As a result, food preservation methods were developed to extend its storage span. One way of extending the shelf life of carabao mango is through drying. Removal of water is necessary so that growth of microorganisms will not manifest.

Drying, a unit operation involving the removal of moisture content (MC) from a wet solid [3], of 
agricultural products is of great importance for the preservation of food by human beings [4]. Drying inhibits the growth of bacteria and has been practiced worldwide since ancient times to preserve food.

Drying mango meat slices until MC of the mango pulp at $12-15 \%$ inhibits the growth of microorganisms and the action of enzymes that causes spoilage [5]. In the food industry, mango is not only dried for the purpose of preservation but also for modification of taste, flavor and texture needed to meet consumer preferences. Color is one of the factors that influence the impact of dried mango in the market. As the mango is being dried, browning occurs. This is due to the oxidation of an enzyme naturally occurring in plants or the operating temperature. Oxidation is a reaction that cannot be prevented after mango has already been peeled while high operating temperatures can lead to deterioration of the nutrients, create off-flavors and induce textural changes [6].

The drying kinetics of food is a complex phenomenon and requires simple representations to predict the drying behavior, and for optimizing the drying parameters. Many investigators have carried out mathematical modeling and experimental studies on the thinlayer drying of various vegetables and fruits [7]. Studies on thin-layer drying were done on potato slices [8], onion slices [9], sweet cherry [10], and banana [11]. However, there is limited information and research on drying kinetics of mango slices in literature [7]. This paper is carried out to develop a drying method to determine the suitable thin-layer mathematical model that describes the drying kinetics of thinly sliced carabao mangoes and subsequently to predict the optimum drying temperature and drying time to attain $12 \% \mathrm{MC}$.

\section{Materials AND METHOdS}

Materials. Fresh, healthy, yellow carabao mangoes from Davao, Philippines with exact ripeness aging from 10-15 days were carefully chosen for this study. The fruits were tapped and patted to feel the exact ripeness. The mangoes were washed, wiped with a clean piece of cloth, peeled manually and sliced into rectangular shape with varied length and width to fill the spaces on the tray but keeping the thickness constant at 5-mm thickness for thinlayer drying using a sterilized stainless steel knife. The procedure was done in an enclosed room with a stainless steel work table and sink for washing up. The whole procedure was carried out hygienically to preserve the freshness of the mangoes free from contaminants.

Hot-air dryer. A hot-air batch dryer was fabricated with dimensions $20 \mathrm{~cm} \times 20 \mathrm{~cm} \times 20$ $\mathrm{cm}$. It was made of aluminum sheets, with its inner part insulated with aluminum laminated air bubble insulation material. It consisted of the following parts: (1) a drying chamber, which housed, (2) a static square tray, (3) a heating element made of an electric coil that is enclosed in a tubular duct, (4) an axial blower that facilitates the distribution of air along the tubular duct towards the drying chamber, (5) a temperature control system that controls and

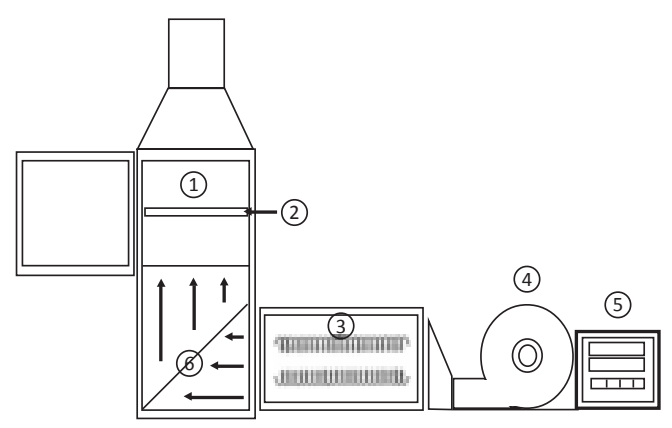

Figure 1. Diagram of the hot-air dryer: (1) drying chamber, (2) tray, (3) heating element, (4) axial blower, (5) temperature control system, (6) air channeling sheet, and (7) exhaust hood. 
displays the temperature in the drying chamber, (6) a perforated air channeling sheet that directs the heated air perpendicularly through the tray, and (7) an air exhaust hood. A diagram of the hot-air dryer is shown in Fig. 1.

Drying experiment. The hot-air dryer was installed in an environment with 30\% relative air humidity and an ambient air temperature of about $28^{\circ} \mathrm{C}$. The air velocity through the dryer was controlled by the speed of the blower. A portable handheld multifunction anemometer TA465 was used to measure the temperature and air velocity inside the hot-air dryer and the relative humidity of the environment.

Single layers of thinly sliced carabao mango were arranged on the tray and was heated at temperatures of $60-80^{\circ} \mathrm{C}$ at $10^{\circ} \mathrm{C}$ intervals every 15 min until constant weight is obtained. The spaces in between the three rows of the mango slices ensure that drying air circulates in the drying chamber and comes in contact with both sides of the mango slices that conform to the conditions of thin-layer drying. Before beginning the experiments, the air dryer system was preheated in order to achieve a desirable steady state condition of temperature at constant air velocity of $0.80 \mathrm{~m} \mathrm{~s}^{-1}$.

Weighing of air-dried mango slices was done using a precision balance with an accuracy of $0.01 \mathrm{~g}$. Drying experiments for each temperature were conducted in triplicate.

Mathematical modeling. The parameters that will be used in the modeling are the moisture ratio (MR) and the drying rate (R). The MR during drying was calculated using Equation 1 :

$$
M R=\frac{M-M_{e}}{M_{i}-M_{e}}
$$

where $\mathrm{M}, \mathrm{M}_{\mathrm{i}}$ and $\mathrm{M}_{\mathrm{e}}$ are the $\mathrm{MC}$, in g, at any time $t$, the initial $\mathrm{MC}$ and the equilibrium $\mathrm{MC}$, respectively. The $\mathrm{R}$ was calculated from the experimental data using Equation 2:

$$
R=-\frac{W_{S}}{A} \frac{d \bar{X}^{\prime}}{d t}
$$

where $\mathrm{W}_{\mathrm{s}}$ is the weight in g, of the dry solid, $\mathrm{A}$ is the surface drying area in $\mathrm{m}^{2}, \bar{X}^{\prime}$ is the bulk MC and $t$ is time. Equation 2 can be rearranged and integrated. The integral form Equation 3 was used to obtain the drying time.

$$
\int_{0}^{t} d t=-\frac{W_{S}}{A} \int_{\bar{X}_{1}^{\prime}}^{\bar{X}_{1}^{\prime}} \frac{d \bar{X}^{\prime}}{R}
$$

The drying data (MR vs. t) at 60,70 and $80^{\circ} \mathrm{C}$ were fitted into the three mathematical models: Page Model, Non-linear Decomposition Model, and Laplace Transform Model. Drying is a complex process and as a means to simplify the analysis of the drying kinetics of mangoes, empirical expressions are used [12]. Mathematical modeling using thin-layer drying equations are used to evaluate drying time of products based from experimental data. Models are often used to study the variables involved in the process, predict drying kinetics of the product and optimize the operating parameters and circumstances [13]. Values of the correlation coefficient, $\mathrm{R}^{2}$, for Page Model and Non-linear Decomposition Model, the time constant, tau, $\tau$ for the Laplace Transform Model and the total error for the three models were computed. The selection of the best model to describe the drying behavior of mango slices will be based on the least total error and the goodness of fit of a model.

The Page Model was successfully used to describe the drying characteristics of some agricultural products [10, 14, 15]. The Page Model $[16,17]$ that was used in this study was derived by linearizing the R equation shown in Equation 4.

$$
M R=a e^{-k t^{n}}
$$


Equation 5 is the linearized form of Equation 4.

$$
M R=\ln a-k t^{n}
$$

The Laplace Transform Model and Non-Linear Decomposition Model are used for prediction of the behavior of a system as reduction of moisture proceeds until it reaches equilibrium [18]. The Laplace Transform Model was derived from a material balance of the system in the experiment. The general material balance states that the input minus the output of the system is equal to the rate of accumulation as shown in Equation 6.

$$
M_{i}-M_{o}=\tau \frac{d M}{d t}
$$

Equation 6 is then formulated to its Laplace Transform Model [19], integrated and simplified forming Equation 7 used in modeling the drying rate characteristics of the carabao mango slices.

$$
M=M_{f}-M_{f} e^{-\frac{t}{\tau}}+M_{i} e^{-\frac{t}{\tau}}
$$

The Non-linear Decomposition Model is based on the differential equation for batch decomposition as given in Equation 8.

$$
\frac{1}{C^{n-1}}=\frac{1}{C_{o}^{n-1}}+(n-1) k t
$$

The determination of the MR is represented by the concentration [20] and is represented below in Equation 9.

$$
M R=\sqrt[n-1]{\frac{M R_{o}^{n-1}}{1+(n-1) k t M R_{o}^{n-1}}}
$$

Determination of drying time to attain 12\% MC. The drying time needed to attain the needed 12\% MC was determined through Lagrange interpolation. This method generates $\mathrm{n}^{\text {th }}$-order polynomials that pass through $(n+1)$ points. These polynomials attempt to produce interpolation values of increased accuracy by assuming a curvature in the relationship of the data. Its general equation is represented by Equation 10. The three versions are Equations 11-13.

The Lagrange interpolation:

$$
f_{n}(x)=\sum_{i=0}^{n} L_{i}(x) f\left(x_{i}\right)
$$

First-Order version:

$$
f_{1}(x)=\frac{x-x_{1}}{x_{0}-x_{1}} f\left(x_{0}\right)+\frac{x-x_{0}}{x_{1}-x_{0}} f\left(x_{1}\right)
$$

Second-Order version:

$$
\begin{aligned}
f_{1}(x)= & \frac{\left(x-x_{1}\right)\left(x-x_{2}\right)}{\left(x_{0}-x_{1}\right)\left(x_{0}-x_{2}\right)} f\left(x_{0}\right)+\frac{\left(x-x_{0}\right)\left(x-x_{2}\right)}{\left(x_{1}-x_{0}\right)\left(x_{1}-x_{2}\right)} f\left(x_{1}\right) \\
& +\frac{\left(x-x_{0}\right)\left(x-x_{1}\right)}{\left(x_{2}-x_{0}\right)\left(x_{2}-x_{1}\right)} f\left(x_{2}\right)
\end{aligned}
$$

Third-Order version:

$$
\begin{aligned}
& f_{3}(x)=\frac{\left(x-x_{1}\right)\left(x-x_{2}\right)\left(x-x_{3}\right)}{\left(x_{0}-x_{1}\right)\left(x_{0}-x_{2}\right)\left(x_{0}-x_{3}\right)} f\left(x_{0}\right)+\frac{\left(x-x_{0}\right)\left(x-x_{2}\right)\left(x-x_{3}\right)}{\left(x_{1}-x_{0}\right)\left(x_{1}-x_{2}\right)\left(x_{1}-x_{3}\right)} f\left(x_{1}\right) \\
& +\frac{\left(x-x_{0}\right)\left(x-x_{1}\right)\left(x-x_{3}\right)}{\left(x_{2}-x_{0}\right)\left(x_{2}-x_{1}\right)\left(x_{2}-x_{3}\right)} f\left(x_{2}\right)+\frac{\left(x-x_{0}\right)\left(x-x_{1}\right)\left(x-x_{2}\right)}{\left(x_{3}-x_{0}\right)\left(x_{3}-x_{1}\right)\left(x_{3}-x_{2}\right)} f\left(x_{3}\right)
\end{aligned}
$$


Quality of dried carabao mango. The air-dried carabao mango slices were stored in sealed containers made from low density polyethylene at an ambient temperature of $28^{\circ} \mathrm{C}$. The air-dried samples were set aside for five weeks to check if browning of the air-dried samples occurs.

\section{RESULTS AND DISCUSSION}

Drying behavior. The drying curves (Fig. 2) show the changes in the experimental data-MR of the mango slices with drying time at indicated temperatures $\left(60,70\right.$ and $\left.80^{\circ} \mathrm{C}\right)$. The drying of the thin mango slices exhibited the characteristic moisture desorption behavior. An initial high rate of moisture removal was followed by slower moisture removal in the latter stages. The characteristic behavior is due to the various forms in which water is present in food products [21]. This is a general trend reported for other food products e.g. mulberry, eggplant, tomatoes, sweet pepper, and peach slices [22-26].

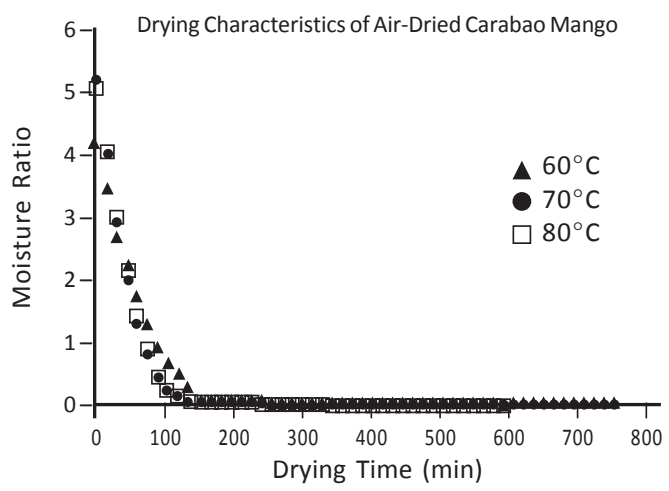

Figure 2. The mean drying characteristics of airdried mango slices at different temperatures
Temperature is one of the main factors that influence the drying kinetics of carabao mango. Drying rate has a direct proportional relationship with temperature making the $\mathrm{R}$ faster at elevated temperature. The shortest drying time to reach equilibrium moisture was obtained using $80^{\circ} \mathrm{C}$ as drying temperature, which only took $570 \mathrm{~min}$., followed by $70^{\circ} \mathrm{C}$, which took $660 \mathrm{~min}$. and finally, $60^{\circ} \mathrm{C}$ which took $735 \mathrm{~min}$. The color of dried mango slices was observed to vary depending on the temperature. As the temperature increased, the product became darker in color.

Mathematical modeling. The MR data were fitted into the three models. The results, namely, values of the correlation coefficient, $R^{2}$, for the Page Model and Non-Linear Decomposition Model, the time constant, tau, $\tau$ for the Laplace Transform Model and the total error for the three models were recorded and are shown in Table 1 . The best results based on the least total error were shown by the Laplace Transform Model at the three temperatures studied. The Laplace Transform Model yielded notable accuracy, precisely modeling the data series of carabao mango slices and predicting its future behavior. Using visual inspection, the Laplace Transform Model also gave the best fit as shown in Fig. 3. Hence, the Laplace Transform Model may be assumed to represent the thinlayer drying behavior of carabao mango slices. Similar findings were reported for the air-drying kinetics of thin slices of coconut meat [19]. Earlier research works reported that the Page Model represent the drying kinetics of raw mango slices [7, 27]. Figure 3 shows the experimental drying kinetic data as they are fitted

Table 1. Summary of Results

\begin{tabular}{c|c|c|c|c|c|c|c|c}
\hline \multirow{2}{*}{ Temp. } & \multicolumn{3}{|c|}{ Page Model } & \multicolumn{3}{c|}{$\begin{array}{c}\text { Non-linear } \\
\text { Decomposition Model }\end{array}$} & \multicolumn{2}{c}{$\begin{array}{c}\text { Laplace } \\
\text { Transform Model }\end{array}$} \\
\cline { 2 - 9 } & $n$ & $R^{2}$ & Total Error & $n$ & $R^{2}$ & Total Error & $\tau$ & Total Error \\
\hline $60^{\circ} \mathrm{C}$ & 0.75 & 0.9572 & 5.7400 & 1.14 & 0.9353 & 2.0536 & 59.0 & 0.3058 \\
\hline $70^{\circ} \mathrm{C}$ & 0.64 & 0.9570 & 6.0859 & 1.19 & 0.9067 & 1.3676 & 41.0 & 0.4843 \\
\hline $80^{\circ} \mathrm{C}$ & 0.66 & 0.9528 & 6.6387 & 1.20 & 0.9469 & 3.7151 & 37.2 & 1.6976 \\
\hline
\end{tabular}


Labutong FIT, Pastores JSF, Yeung AC, \& Pestaño LDB | Acta Manilana 64 (2016)
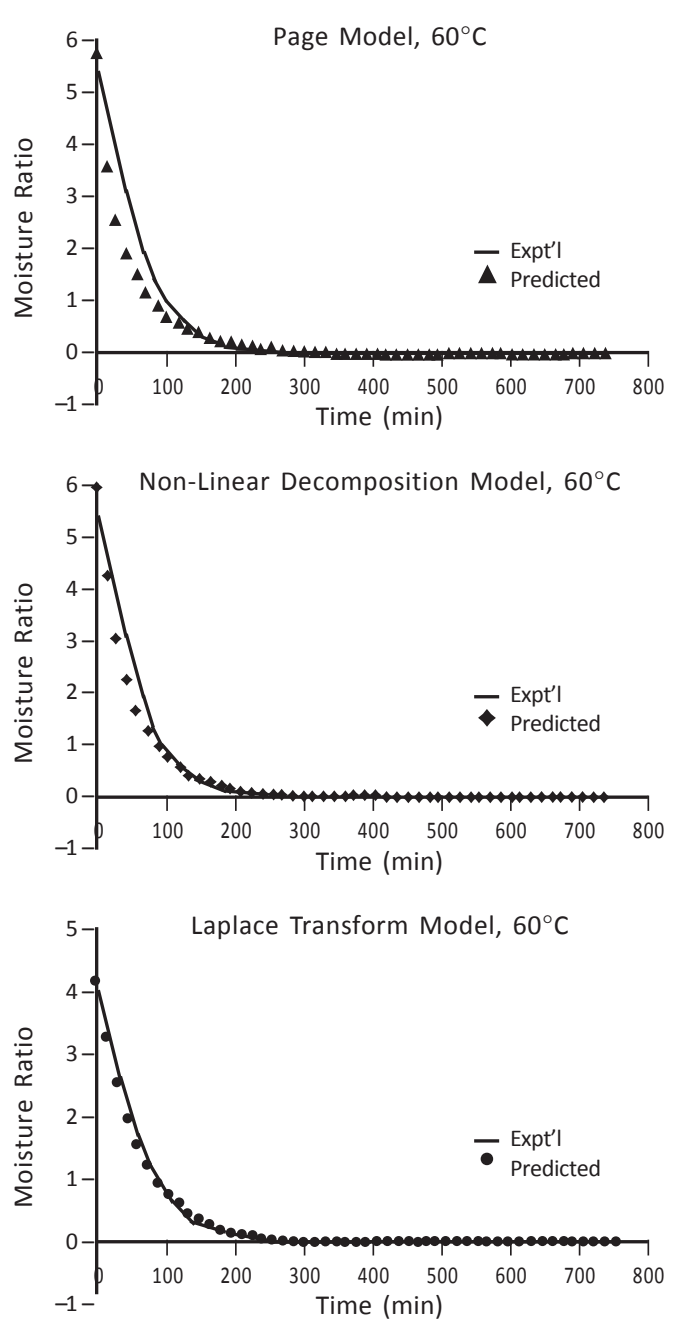

Figure 3. Comparison of the experimental and predicted values of MR vs. time at $60^{\circ} \mathrm{C}$ using the three models

Table 2. Calculated drying time at different treatment temperatures as predicted by the Laplace Transform Model

\begin{tabular}{c|c|c|c}
\hline \multirow{2}{*}{ Trial No. } & \multicolumn{3}{|c}{ Temperature } \\
\cline { 2 - 4 } & $60^{\circ} \mathrm{C}$ & $70^{\circ} \mathrm{C}$ & $80^{\circ} \mathrm{C}$ \\
\hline 1 & $209.51 \mathrm{~min}$ & $154.67 \mathrm{~min}$ & $139.28 \mathrm{~min}$ \\
\hline 2 & $215.24 \mathrm{~min}$ & $154.28 \mathrm{~min}$ & $139.21 \mathrm{~min}$ \\
\hline 3 & $215.54 \mathrm{~min}$ & $139.96 \mathrm{~min}$ & $139.17 \mathrm{~min}$ \\
\hline
\end{tabular}

with the simulated models at $60^{\circ} \mathrm{C}$ drying temperature.

Drying time analysis. The drying time for the carabao mango slices to reach the desired MC of $12 \%$ at which the growth of microorganisms is unlikely to occur was significantly affected by the drying temperature. The Laplace Transform Model was used to predict the optimum drying time at which the MC of the mango slices will be $12 \%$. The drying time was computed using Lagrange interpolation. The average drying time to reach $12 \% \mathrm{MC}$ from the initial range of $42-50 \%$ was $213.43,149.44$ and $139.22 \mathrm{~min}$ at drying temperatures of 60,70 and $80^{\circ} \mathrm{C}$, respectively. Table 2 shows the calculated heating time as predicted by the Laplace Transform Model. A shorter heating time at $80^{\circ} \mathrm{C}$ was utilized to attain a $12 \% \mathrm{MC}$ in the mango slices except for $70^{\circ} \mathrm{C}$ at Trial 3 due to changes in the surrounding conditions, which affected the ability of the air to absorb moisture.

Observation of the color of the air-dried mango pulp. The appearances of dark spots that indicate the growth of microorganism were monitored by visual inspection from the air-dried mangoes. With 1-week interval of monitoring, it was observed that after 5 weeks, browning of the mango pulp was not evident for all air-dried carabao mango samples. The retention of the yellow color of the mango pulp is due to the removal of water using hot-air drying that inhibits the growth of microorganisms.

\section{Conclusion}

A drying method was developed using a hot-air dryer to determine the drying kinetics of carabao mango. The Laplace Transform Model best fits the drying kinetics of thinly sliced carabao mango with the least total error and good visual inspection. The optimum drying temperature was observed to be at $60^{\circ} \mathrm{C}$ being more efficient to produce quality dried carabao mangoes at 
the shortest drying time of 209.51 min to reach a MC of $12 \%$ wet basis.

$$
\begin{aligned}
& \text { Nomenclature } \\
& M \text { - mass of mangoes and water, } \mathrm{g} \text { at any time, } \\
& \mathrm{t} \\
& M_{e} \text { - equilibrium moisture content, g water; } \\
& M_{i} \text { - initial moisture content, g water at } \mathrm{t}=0 \\
& M R \text { - moisture ratio } \\
& M C \text { - moisture content at any time, g water at }
\end{aligned}
$$

\section{Greek Letters}

$t$ - residence time, $\min$

$$
\begin{aligned}
& \text { Subscripts } \\
& \qquad \begin{array}{l}
f \quad \text { - final } \\
i, o-\text { initial } \\
e \quad-\text { equilibrium }
\end{array}
\end{aligned}
$$

\section{AcKNowledgments}

The authors gratefully acknowledge the helpful comments and suggestions of Engr. Beatriz A. Belmonte, Engr. Mark Emile H. Punzalan and Ms. Essence Jean P. Logan.

\section{REFERENCES}

[1] FAO, 2013 Commodity and Trade Policy Research Working Paper No. 42. Market Structure and Distribution of Benefits from Agricultural Exports: The Case of the Philippine Mango Industry. http://www.fao.org/3/aar709e.pdf accessed: 30/01/2017

[2] Delmo G. Carabao mango: Philippine's sweet pride. Far Eastern Agriculture, 2010. Retrieved 1 August 2014. From http:// www.businessmirror.com.ph/en/business/ entrepreneur/32407-pmsfc-modernizing-mangofarming-in-phl
[3] Levenspiel O. Chemical Reaction Engineering. (John Wiley \& Sons, 2003).

[4] Togul I \& Pehlivan D. Modelling of Thin Layer Drying Kinetics of Some Fruits Under Open-Air Sun Drying Process. Journal of Food Engineering 2004.

[5] Clary C, Farid M, Fasina O, Hui Y, Noomhorm A, \& Welti-Chanes J. Food Drying Science and Technology: Microbiology, Chemistry, Applications. In: Sablani S \& Rahman S, Fundamentals of Food Dehydration, pp. 1-2. (Lancaster: DEStech Publications Inc., 2008).

[6] Da Silva WP, Silva CMDPS, Gama FJ, \& Gomes JP. Mathematical models to describe thin-layer drying and to determine drying rate of whole bananas. Journal of the Saudi Society of Agricultural Sciences 2014; 13:(1),67-74.

[7] Akoy EOM. Experimental characterization and modeling of thin-layer drying of mango slices. International Food Research Journal 2014; 21(5):1911-1917.

[8] Aghbashlo M, Kianmehr MH, \& Arabhosseini A. Modeling of thin-layer drying of potato slices in length of continuous band dryer. Energy Conservation and Management 2009; 50:13481355.

[9] Arslan D \& Özcan MM. Study the effect of sun, oven and microwave drying on quality of onion slices. LWT-Food Science and Technology 2010; 43:1121-1227.

[10] Doymaz I \& Ismail O. Drying characteristics of sweet cherry. Food and Bioproducts Processing 2011; 89:31-38.

[11] da Siva WP, Silva C, Gama F, \& Gomes J. Mathematical models to describe thin- layer drying and to determine drying rate of whole bananas. Journal of the Saudi Society of Agricultural Sciences 2013. htt:// dx.doi.org/10.1016/ j.jssas.2013.01.003.

[12] Clary C, Farid M, Fasina O, Hui Y, Noomhorm A, \& Welti-Chanes J. Food Drying Science and Technology: Microbiology, Chemistry, Applications. In: Lypez-Malo A \& Rios-Casas L Solar Assisted Drying of Foods, p. 84. (Lancaster: DEStech Publications Inc., 2008).

[13] Belessiotis VG \& Karathanos VT. Application of a thin layer equation to drying data fresh and semi-dried fruits. Agricultural Engineering Resources 1999; 355-361.

[14] Singh S, Raina GS, Bawa AS, \& Saxena DG. Effect of pretreatments on drying and rehydration kinetics and colour of sweet potato slices. Drying Technology 2006; 24:1487-1497. 
Labutong FIT, Pastores JSF, Yeung AC, \& Pestaño LDB | Acta Manilana 64 (2016)

[15] Hassan-Beygi SR, Aghbashlo M, Kinamehr MH, \& Massad J. Drying characteristics of walnut (Juglan regia L.) during convection drying. International Agrophysics 2009; 23:129-135.

[16] Agrawal YC \& Singh RC. Thin layer drying studies on short grain rough rice (ASAE Paper No. 773531. (MI, U.S.A.: St. Joseph, 1977).

[17] Zhang Q \& Litchfield JB. An optimization of Intermittent corn drying in a laboratory scale thin layer dryer. Drying Technology 1991; 9:383-395.

[18] Charbonnel C, Ghoul M, Guiga W, \& Ioannou I. Food and Bioproducts Processing Frozen mirabelle plum drying: Kinetics, modeling and impact on biochemical properties. (2010)

[19] Pestaño LB. Mathematical Modeling of the drying process of coconut meat [Online]. In: Third International Conference on Advances in Applied Science and Environmental Engineering (ASEE 2015) (USA: CInstitute of Research Engineers and Doctors, 2015). ISBN: 978-1-63248-055-2.

[20] Jose WI \& Pestaño LB. Engineering an Improved Coconut Processing System in the Philippines at the Farm-Level. Journal of Advanced Agricultural Technologies 2016; 3(1):58-62.
[21] Tunde-Akintunde TY \& Afon AA. Modelling of hot-air drying of pretreated cassava chips. Agricultural Engineering International (CIGR Ejournal, Manuscript 1493) 2009.

[22] Doymaz I. Pretreatment effect on sun drying of mulberry fruits (Morus alba L.). Journal of Food Engineering 2004; 78:591-596.

[23] Ertekin C \& Yaldiz O. Drying of eggplant and selection of a suitable thin layer drying model. Journal of Food Engineering 2004; 63:349-359.

[24] Doymaz I. Air-drying characteristics of tomatoes. Journal of Food Engineering 2007; 78:12911297.

[25] Vengaiah PC \& Pandey JP. Dehaydration kinetics of sweet pepper. (Capsicum annum L.). Journal of Food Engineering 2007; 81:282-286.

[26] Kingsly RP, Goyal RK, Manikantan MR, and llyas SM. Effects of pretreatments and drying air temperature on drying behaviour of peach slice. International Journal of Food Science and Technology 2007; 4:65-69.

[27] Goyal RK, Kingsly ARP, Manikantan MR, \& llyas SM. Thin-layer drying kinetics of raw mango slices. Biosystems Enginerring 2006; 95(1):4349. 